\title{
INCAPACITY FOR WORK AMONG THE INSURED POPULATION OF GREAT BRITAIN
}

\author{
BY \\ G. MARY JONES \\ The Ministry of Pensions and National Insurance
}

The Ministry of Pensions and National Insurance usually receives between eight and nine million new claims for sickness and injury benefits in a year and records certified incapacity for work totalling nearly 300 million days. Detailed analyses are made from the records of spells of incapacity for work in respect of 5 per cent. of the insured population. These analyses are designed to show the extent and causes of incapacity, as given on the medical certificates, among different age groups and in different areas: broadly they show the position over the course of a year running from the first Monday in June, and at the end of the period. Illnesses which do not cause incapacity for work are not covered,

TABLE IA

HOME POPULATION AGED 15-69 (MALES) AND 15-64 (FEMALES) IN DECEMBER 1955, SHOWING ESTIMATED NUMBERS INSURED FOR SICKNESS AND INJURY BENEFITS (MILLIONS)

\begin{tabular}{|c|c|c|c|c|c|c|}
\hline \multirow{2}{*}{\multicolumn{2}{|c|}{ Sex }} & \multirow[b]{2}{*}{ Total } & \multirow[b]{2}{*}{$\begin{array}{c}\begin{array}{c}\text { Not } \\
\text { Insured }\end{array} \\
\text { (1) }\end{array}$} & \multicolumn{3}{|c|}{ Insured for: } \\
\hline & & & & $\begin{array}{c}\text { Sickness } \\
\text { Benefit } \\
\text { Only } \\
\text { (2) }\end{array}$ & $\begin{array}{c}\text { Sickness } \\
\text { and } \\
\text { Injury } \\
\text { Benefits } \\
\text { (3) }\end{array}$ & $\begin{array}{c}\text { Injury } \\
\text { Benefit } \\
\text { Only } \\
\text { (4) }\end{array}$ \\
\hline Male & .. & $16 \cdot 70$ & $1 \cdot 62$ & $1 \cdot 30$ & $13 \cdot 68$ & $0 \cdot 10$ \\
\hline Female & $\begin{array}{l}\text { Married } \\
\text { Other }\end{array}$ & $\begin{array}{r}11 \cdot 60 \\
5 \cdot 21\end{array}$ & $\begin{array}{l}7 \cdot 79 \\
1 \cdot 29\end{array}$ & $\begin{array}{l}0 \cdot 33 \\
0 \cdot 14\end{array}$ & $\begin{array}{l}1.42 \\
3.61\end{array}$ & $\begin{array}{l}2 \cdot 06 \\
0 \cdot 17\end{array}$ \\
\hline
\end{tabular}

(1) Non-employed, including students, housewives, and retired persons; and members of the armed forces in Great Britain.

(2) Self-employed, and people who have recently given up gainful employment but retain residual rights to benefit.

(3) Employed persons other than those included in (4). The figures include civil servants $(460,000$ men, 30,000 married women, and 130,000 other women) who do not normally claim sickness or injury benefit during the first 6 months of incapacity for work and who are therefore excluded from the "population at risk figures" in Table IB.

(4) Employed married women who choose not to be insured for sickness benefit and certain widows with a similar option; also late age entrants contributing for injury benefit and retirement pension only, and employed retirement pensioners. and very short spells of incapacity lasting less than 4 days do not normally attract payment of benefit and are commonly not reported to the Ministry. To that extent the Tables are deficient as an indication of the extent of illness among insured persons.

The latest analyses* are in respect of the years from June 7, 1954, to June 4, 1955, and from June 6, 1955, to June 2, 1956, and the Tables and Charts which follow illustrate the position shown by the figures in one or both of those periods.

\section{SCOPE OF THE Figures}

The people represented in, and excluded from, the analyses are indicated in Table $I_{A}$ and $I_{B}$, and Fig. 1(a) (opposite).

Broadly, the analyses cover incapacity for work by reason of sickness among gainfully occupied civilian men between the ages of 15 and 69. They do not

TABLE IB

PROPORTION* OF THE POPULATION IN EACH QUINQUENNIAL AGE GROUP AT RISK FOR SICKNESS BENEFIT

\begin{tabular}{|c|c|c|c|c|c|c|}
\hline \multirow{3}{*}{$\begin{array}{c}\text { Quin- } \\
\text { quennial } \\
\text { Age } \\
\text { Groups } \\
\text { (at } \\
\text { 31.12.55) }\end{array}$} & \multicolumn{3}{|c|}{ Males } & \multicolumn{3}{|c|}{ Females } \\
\hline & \multirow{2}{*}{$\begin{array}{c}\text { Number } \\
\text { in Age } \\
\text { Group } \\
\text { (thous- } \\
\text { ands) }\end{array}$} & \multicolumn{2}{|c|}{$\begin{array}{l}\text { At Risk for } \\
\text { Sickness Benefit }\end{array}$} & \multirow{2}{*}{$\begin{array}{l}\text { Number } \\
\text { in Age } \\
\text { Group } \\
\text { (thous- } \\
\text { ands) }\end{array}$} & \multicolumn{2}{|c|}{$\begin{array}{c}\text { At Risk for } \\
\text { Sickness Benefit }\end{array}$} \\
\hline & & $\begin{array}{l}\text { Thous- } \\
\text { ands }\end{array}$ & $\begin{array}{c}\text { Per } \\
\text { cent. }\end{array}$ & & $\begin{array}{l}\text { Thous- } \\
\text { ands }\end{array}$ & $\begin{array}{l}\text { Per } \\
\text { cent. }\end{array}$ \\
\hline $\begin{array}{l}15-19 \\
20-24 \\
25-29 \\
30-34 \\
35-39 \\
40-44 \\
45-49 \\
50-54 \\
55-59 \\
60-64 \\
65-69\end{array}$ & $\begin{array}{l}1,545 \\
1,527 \\
1,664 \\
1,812 \\
1,647 \\
1,787 \\
1,799 \\
1,649 \\
1,331 \\
1,072 \\
867\end{array}$ & $\begin{array}{r}1,021 \\
1,173 \\
1,560 \\
1,682 \\
1,530 \\
1,672 \\
1,745 \\
1,578 \\
1,243 \\
993 \\
.323\end{array}$ & $\begin{array}{l}\mathbf{6 6} \cdot 1 \\
76.8 \\
93.7 \\
92.8 \\
92.9 \\
93.6 \\
97.0 \\
95.7 \\
93.4 \\
92.6\end{array}$ & $\begin{array}{c}1,581 \\
1,579 \\
1,671 \\
1,836 \\
1,703 \\
1,857 \\
1,852 \\
1,758 \\
1,582 \\
1,395 \\
-\end{array}$ & $\begin{array}{r}1,209 \\
1,080 \\
570 \\
368 \\
301 \\
372 \\
437 \\
470 \\
416 \\
124 \\
-\end{array}$ & $\begin{array}{c}76 \cdot 5 \\
68 \cdot 4 \\
34 \cdot 1 \\
20 \cdot 0 \\
17 \cdot 7 \\
20 \cdot 0 \\
23 \cdot 6 \\
26 \cdot 7 \\
26 \cdot 3 \\
8.9 \\
-\end{array}$ \\
\hline Ages & 16,700 & 14,520 & 86.9 & 16,814 & 5,347 & $31 \cdot 8$ \\
\hline
\end{tabular}

- Based on average population at risk between June, 1955, and June, 1956.

tIncluding those entitled to contribution credits only.

* "Digest of Statistics Analysing Certificates of Incapacity, 1954-55 and 1955-56"; available to research workers on application to the Ministry of Pensions and National Insurance (Division C.3), 10 John Adam Street, London, W.C.2. 
cover men in the armed forces, students, or retired persons; or certain men aged 65-69 who were late entrants to insurance; or people who have never worked. As the chart shows, the proportion not covered for sickness benefit is small, and Fig. 1(b) indicates that the majority of exclusions are at the upper and lower ends of the age range. All employed men, whatever their age, are insured for industrial injuries.
Among women aged 15-64, the proportion represented in statistics of sickness benefit is relatively small, especially from age $\mathbf{2 5}$ onwards. Among single wonien the exclusions are the same as among the men, but gainfully occupied married women can choose whether or not to pay contributions, and in 1956 little more than one-third of those in employment chose to do so. A similar option is also available to certain widows. Housewives are not covered

(a) POPULATION AND NUMBERS INSURED

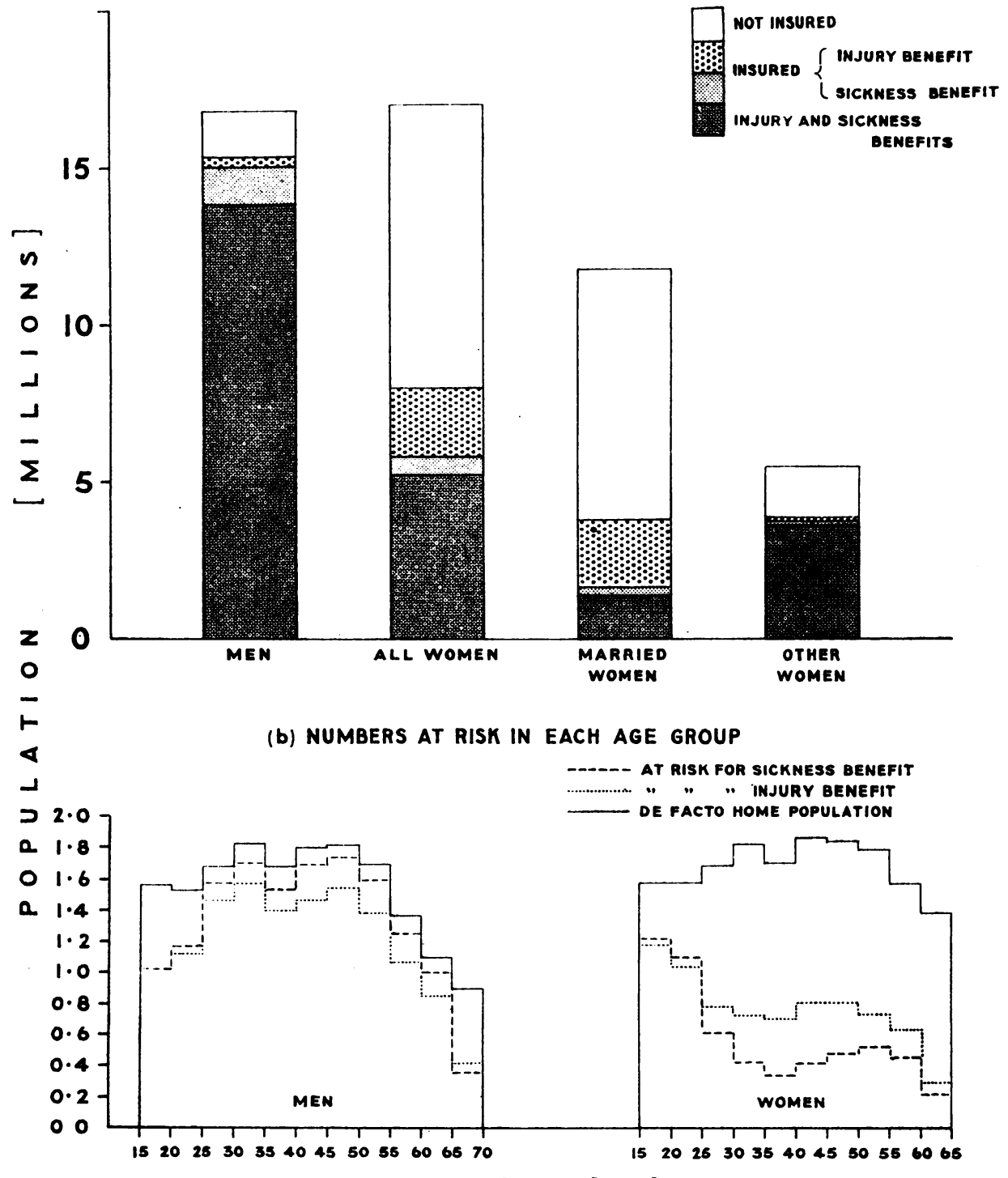

A GE [YRS]

Fio. 1.-Home population aged 15-69 (men) and 15-64 (women) in December, 1955, showing estimated numbers insured for sickness and injury benefits and average numbers at risk in each age group. 
except in so far as they may retain a right to benefit for a period immediately after ceasing employment. All employed women are insured for industrial injuries.

Under their sick pay arrangements, civil servants though insured, do not normally claim National Insurance sickness or injury benefits for incapacity lasting less than 6 months, and as such incapacity is not included in the Tables they are excluded from the population at risk. No one aged 70 or over (65 for women) is insured for sickness benefit. At the other end of the age range, new entrants to insurance have to pay 26 contributions before becoming eligible for benefit, but while these contributions are being paid they are usually entitled to have contributions credited for periods of incapacity, and if medical certificates are submitted for this purpose, their illnesses are included in the Tables.

\section{SiCKNESS BENEFIT}

The numbers insured, the numbers drawing benefit, and the extent of claims are indicated in Table II.

The pattern of claiming was similar in both years under review. Of those at risk, 28 per cent. of the men and 32 per cent. of the women claimed benefit, most of them once only; the proportion making two claims amounted to 5 per cent. of the men and 6 per cent. of the women, while in both only 2 per cent. claimed three times or more. The number of days of incapacity recorded in each year per person at risk amounted to about thirteen for men and between 16 and 17 for women.

Table III (opposite) shows how long the claimants had been incapacitated at quarterly dates in 1954-55.

Even in the winter months, when short-term claims were at their highest level, the proportion of men who had been incapacitated for 6 months or more did not fall below a third of the total number registered, and over the year the average was about 40 per cent; the proportion incapacitated for 2 years or more varied in the year from one-fifth to just over one-quarter. The proportions were higher among women than among men. The actual numbers incapacitated for long periods varied little. The number of men who had been incapacitated for longer than 6 months remained close to 250,000 , of whom 150,000 had been incapacitated for over 2 years; corresponding figures for women varied only from about 135,000 to 141,000 over 6 months, of whom some 92 to 96,000 had been incapacitated for over 2 years.
TABLE II

SICKNESS BENEFIT: EXTENT OF CLAIMS IN THE PERIODS FROM JUNE 7, 1954, TO JUNE 4, 1955, AND FROM JUNE 6, 1955, TO JUNE 2, 1956

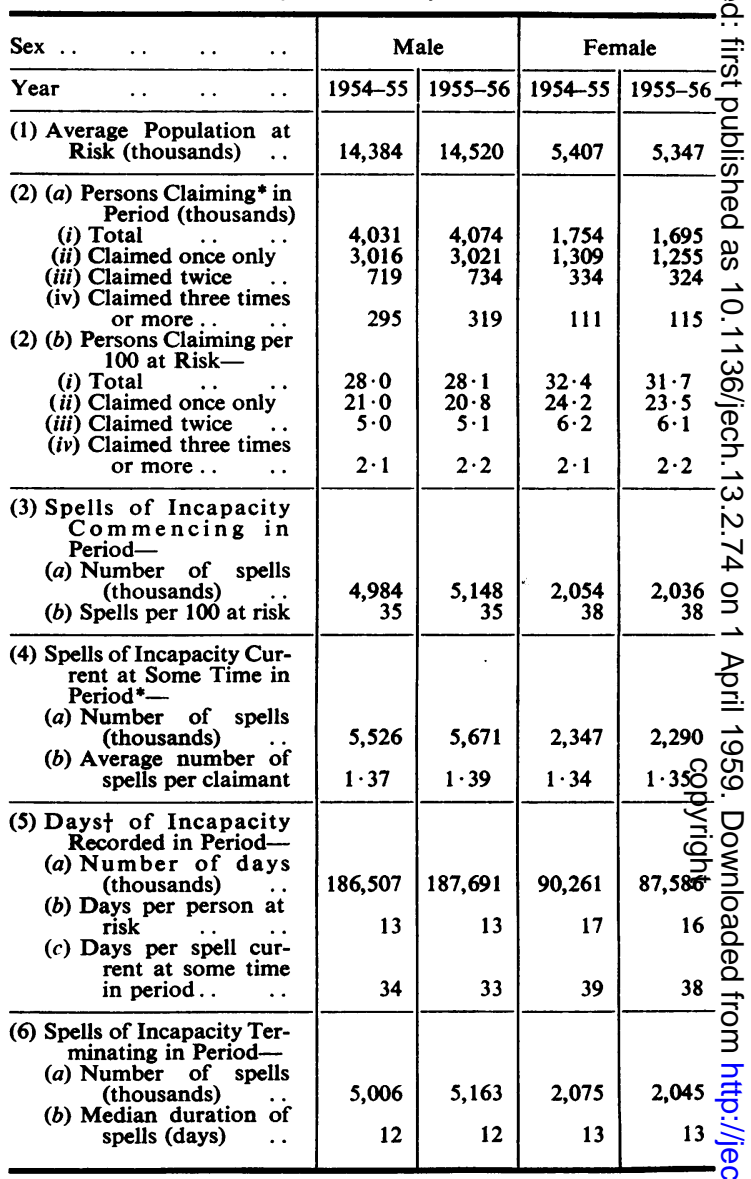

* For 1954-55 these figures are based on the analysis of a sub-? sample equal to about 1 per cent. of the whole.

+ Week-days: 6 days $=$ one week; 312 days $=$ one year.

\section{Variations With Age}

As might be expected, the incidence of incapacity $\frac{7}{O}$ varied with age (Table IV, opposite, and Fig. 2, overleaf). Among men aged 15-24, a slightly higher pro-N portion were incapacitated at some time in the year than at higher ages under 50 . The lowest proportion ${ }_{N}$ was in the age range from $25-29$, and there was little $\omega$ variation from $30-44$, but from then onwards the proportion increased rapidly and the maximum of 41 per hundred persons at risk in the age range $\mathbb{\Phi}_{\mathbb{D}}$ 60-64 was some 70 per cent. higher than the mini-? mum of 24 per hundred between the ages of 25-29. $\frac{T}{0}$ The increase with age in the proportion of persons $\frac{\mathrm{O}}{\mathbb{Q}}$ 
TABLE III

NUMBERS OF CLAIMANTS INCAPACITATED AT QUARTERLY DATES ANALYSED BY DURATION OF SPELL AT THOSE DATES

\begin{tabular}{|c|c|c|c|c|c|c|c|}
\hline \multirow{2}{*}{\multicolumn{3}{|c|}{ Claimants }} & \multirow{2}{*}{ Sex } & \multicolumn{4}{|c|}{ Dates } \\
\hline & & & & September 4, 1954 & December 4, 1954 & March 5, 1955 & June 4, 1955 \\
\hline Number Incapacitated & .. & . & \multirow[b]{2}{*}{ Male } & 547,900 & 665,400 & 752,900 & 569,900 \\
\hline $\begin{array}{cc}\text { Percentage } & \text { Incapaci- } \\
\text { tated for } & \text { Duration } \\
\text { Shown } & \cdots\end{array}$ & \multicolumn{2}{|c|}{ 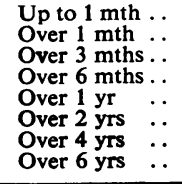 } & & $\begin{array}{l}30 \\
70 \\
55 \\
47 \\
37 \\
27 \\
17 \\
10 \\
\end{array}$ & $\begin{array}{r}42 \\
58 \\
44 \\
38 \\
31 \\
22 \\
14 \\
9\end{array}$ & $\begin{array}{r}42 \\
58 \\
41 \\
33 \\
27 \\
20 \\
13 \\
8\end{array}$ & $\begin{array}{l}31 \\
69 \\
53 \\
44 \\
36 \\
26 \\
17 \\
11 \\
\end{array}$ \\
\hline Number Incapacitated & $\cdots \quad \cdots$ & $\cdots$ & \multirow[b]{2}{*}{ Female } & 283,100 & 313,900 & 328,300 & 262,300 \\
\hline \begin{tabular}{ccc} 
Percentage & \multicolumn{2}{l}{ Incapaci- } \\
tated for & Duration \\
Shown & $\ldots$ & $\ldots$
\end{tabular} & \multicolumn{2}{|c|}{$\begin{array}{l}\text { Up to } 1 \text { mth } \ldots \\
\text { Over } 1 \text { mth } \ldots \\
\text { Over } 3 \text { mths.. } \\
\text { Over } 6 \text { mths .. } \\
\text { Over } 11 \text { yr } \quad \ldots \\
\text { Over } 2 \text { yrs } \quad \ldots \\
\text { Over } 4 \text { yrs } \quad \ldots \\
\text { Over } 6 \text { yrs } \quad \ldots\end{array}$} & & $\begin{array}{l}30 \\
70 \\
57 \\
50 \\
42 \\
34 \\
26 \\
19\end{array}$ & $\begin{array}{l}38 \\
62 \\
50 \\
44 \\
37 \\
30 \\
22 \\
17\end{array}$ & $\begin{array}{l}37 \\
63 \\
48 \\
42 \\
36 \\
28 \\
21 \\
16\end{array}$ & $\begin{array}{l}28 \\
72 \\
59 \\
52 \\
44 \\
35 \\
26 \\
20\end{array}$ \\
\hline
\end{tabular}

TABLE IV

EXTENT OF INCAPACITY FOR WORK IN DIFFERENT AGE GROUPS

\begin{tabular}{|c|c|c|c|c|c|c|c|c|c|c|c|c|c|}
\hline \multirow{2}{*}{ Extent of Incapacity } & \multirow{2}{*}{ Sex } & \multirow{2}{*}{ Year } & \multicolumn{10}{|c|}{ Age at December 31} & \multirow{2}{*}{$\underset{\text { Ages* }}{\text { All }}$} \\
\hline & & & 15-19 & $20-24$ & $25-29$ & $30-34$ & $35-39$ & $40-44$ & $45-49$ & $50-54$ & $55-59$ & $60-64$ & \\
\hline \multirow{2}{*}{$\begin{array}{c}\text { Average Population at } \\
\text { Risk (thousands) }\end{array}$} & Male & $\begin{array}{l}1954-5 \\
1955-6\end{array}$ & $\begin{array}{l}1,000 \\
1,021\end{array}$ & $\begin{array}{l}1,178 \\
1,173\end{array}$ & $\begin{array}{l}1,566 \\
1,560\end{array}$ & $\begin{array}{l}1,749 \\
1,682\end{array}$ & $\begin{array}{l}1,447 \\
1,530\end{array}$ & $\begin{array}{l}1,695 \\
1,672\end{array}$ & $\begin{array}{l}1,727 \\
1,745\end{array}$ & $\begin{array}{l}1,538 \\
1,578\end{array}$ & $\begin{array}{l}1,182 \\
1,243\end{array}$ & $\begin{array}{l}977 \\
993\end{array}$ & $\begin{array}{l}14,384 \\
14,520\end{array}$ \\
\hline & Female & $\begin{array}{l}1954-5 \\
1955-6\end{array}$ & $\begin{array}{l}1,206 \\
1,209\end{array}$ & $\begin{array}{l}1,080 \\
1,080\end{array}$ & $\begin{array}{l}575 \\
570\end{array}$ & $\begin{array}{l}382 \\
368\end{array}$ & $\begin{array}{l}302 \\
301\end{array}$ & $\begin{array}{l}391 \\
372\end{array}$ & $\begin{array}{l}455 \\
437 \\
\end{array}$ & $\begin{array}{l}472 \\
470 \\
\end{array}$ & $\begin{array}{l}415 \\
416\end{array}$ & - & $\begin{array}{l}5,407 \\
5,347 \\
\end{array}$ \\
\hline \multirow{2}{*}{$\begin{array}{l}\text { Number of Days of In- } \\
\text { capacity in Period } \\
\text { (thousands) }\end{array}$} & Male & $\begin{array}{l}1954-5 \\
1955-6\end{array}$ & $\begin{array}{l}5,530 \\
5,329\end{array}$ & $\begin{array}{l}8,143 \\
7,690 \\
\end{array}$ & $\begin{array}{l}10,866 \\
10,077 \\
\end{array}$ & $\begin{array}{l}13,433 \\
12,715 \\
\end{array}$ & $\begin{array}{l}12,290 \\
12,636\end{array}$ & $\begin{array}{l}16,072 \\
15,960 \\
\end{array}$ & $\begin{array}{l}19,746 \\
20,074\end{array}$ & $\begin{array}{l}25,137 \\
25,016\end{array}$ & $\begin{array}{l}30,183 \\
31,328\end{array}$ & $\begin{array}{l}37,859 \\
39,505\end{array}$ & $\begin{array}{l}186,510 \\
187,691\end{array}$ \\
\hline & Female & $\begin{array}{l}1954-5 \\
1955-6\end{array}$ & $\begin{array}{l}8,695 \\
8,144\end{array}$ & $\begin{array}{l}11,302 \\
11,188\end{array}$ & $\begin{array}{l}7,623 \\
6,974\end{array}$ & $\begin{array}{l}6,627 \\
5,844\end{array}$ & $\begin{array}{l}5,376 \\
5,687\end{array}$ & $\begin{array}{l}7,912 \\
7,384\end{array}$ & $\begin{array}{l}10,966 \\
10,561 \\
\end{array}$ & $\begin{array}{l}13,650 \\
13,508\end{array}$ & $\begin{array}{l}16,252 \\
16,442\end{array}$ & - & $\begin{array}{l}90,260 \\
87,586\end{array}$ \\
\hline \multirow{2}{*}{$\begin{array}{l}\text { Number of Spells of In- } \\
\text { capacity Commencing } \\
\text { in Period (thousands) }\end{array}$} & Male & $\begin{array}{l}1954-5 \\
1955-6\end{array}$ & $\begin{array}{l}340 \cdot 3 \\
336 \cdot 5\end{array}$ & $\begin{array}{l}406 \cdot 3 \\
410 \cdot 1\end{array}$ & $\begin{array}{l}498 \cdot 3 \\
500 \cdot 9\end{array}$ & $\begin{array}{l}567 \cdot 9 \\
569 \cdot 3\end{array}$ & $\begin{array}{l}465 \cdot 2 \\
501 \cdot 4\end{array}$ & $\begin{array}{l}528 \cdot 0 \\
542 \cdot 6\end{array}$ & $\begin{array}{l}562 \cdot 0 \\
576.9\end{array}$ & $\begin{array}{l}564 \cdot 9 \\
590 \cdot 7\end{array}$ & $\begin{array}{l}485 \cdot 2 \\
529 \cdot 1\end{array}$ & $\begin{array}{l}420 \cdot 3 \\
442 \cdot 4\end{array}$ & $\begin{array}{l}4,983 \cdot 6 \\
5,148 \cdot 2\end{array}$ \\
\hline & Female & $\begin{array}{l}1954 \cdot 5 \\
1955-6\end{array}$ & $\begin{array}{l}491 \cdot 6 \\
482 \cdot 3\end{array}$ & $\begin{array}{r}457 \cdot 9 \\
458 \cdot 4 \\
\end{array}$ & $\begin{array}{l}202 \cdot 6 \\
201 \cdot 1 \\
\end{array}$ & $\begin{array}{l}140 \cdot 9 \\
131 \cdot 1\end{array}$ & $\begin{array}{l}111 \cdot 3 \\
117 \cdot 2\end{array}$ & $\begin{array}{l}139.6 \\
136.8\end{array}$ & $\begin{array}{l}165 \cdot 2 \\
162 \cdot 0 \\
\end{array}$ & $\begin{array}{l}169 \cdot 6 \\
168 \cdot 9\end{array}$ & $\begin{array}{l}141 \cdot 0 \\
144 \cdot 0\end{array}$ & - & $\begin{array}{l}2,053 \cdot 5 \\
2,035 \cdot 7\end{array}$ \\
\hline \multirow{2}{*}{$\begin{array}{l}\text { Persons Incapacitated at } \\
\text { Some Time in Period } \\
\text { (thousands) } \ldots\end{array}$} & Male & $\begin{array}{l}1954-5 \\
1955-6\end{array}$ & $\begin{array}{l}265 \cdot 4 \\
266 \cdot 4\end{array}$ & $\begin{array}{l}319 \cdot 7 \\
313.9\end{array}$ & $\begin{array}{l}375 \cdot 0 \\
372 \cdot 7\end{array}$ & $\begin{array}{l}428 \cdot 5 \\
416 \cdot 8\end{array}$ & $\begin{array}{l}355 \cdot 1 \\
375 \cdot 4\end{array}$ & $\begin{array}{l}414 \cdot 8 \\
416 \cdot 0\end{array}$ & $\begin{array}{l}455 \cdot 9 \\
452 \cdot 5\end{array}$ & $\begin{array}{l}462 \cdot 4 \\
472 \cdot 9\end{array}$ & $\begin{array}{l}425 \cdot 9 \\
442 \cdot 5\end{array}$ & $\begin{array}{l}398 \cdot 2 \\
409 \cdot 4\end{array}$ & $\begin{array}{l}4,030 \cdot 5 \\
4,074 \cdot 4 \\
\end{array}$ \\
\hline & Female & $\begin{array}{l}1954-5 \\
1955-6\end{array}$ & $\begin{array}{l}380.4 \\
360.4\end{array}$ & $\begin{array}{l}358 \cdot 7 \\
348 \cdot 0\end{array}$ & $\begin{array}{l}174 \cdot 7 \\
162 \cdot 2 \\
\end{array}$ & $\begin{array}{l}115 \cdot 9 \\
108 \cdot 4 \\
\end{array}$ & $\begin{array}{l}90 \cdot 3 \\
98 \cdot 3\end{array}$ & $\begin{array}{l}124 \cdot 6 \\
116 \cdot 7 \\
\end{array}$ & $\begin{array}{l}151 \cdot 1 \\
146 \cdot 6 \\
\end{array}$ & $\begin{array}{l}165 \cdot 2 \\
161 \cdot 7\end{array}$ & $\begin{array}{l}154.4 \\
155 \cdot 9 \\
\end{array}$ & - & $\begin{array}{l}1,754 \cdot 0 \\
1,694 \cdot 9 \\
\end{array}$ \\
\hline \multirow{2}{*}{$\begin{array}{c}\text { Days of Incapacity in } \\
\text { Period, per } 100 \text { Persons } \\
\text { at Risk } \\
\ldots\end{array}$} & Male & $\begin{array}{l}1954-5 \\
1955-6\end{array}$ & $\begin{array}{l}553 \\
522\end{array}$ & $\begin{array}{l}691 \\
656\end{array}$ & $\begin{array}{l}694 \\
646\end{array}$ & $\begin{array}{l}768 \\
756 \\
\end{array}$ & $\begin{array}{l}849 \\
826\end{array}$ & $\begin{array}{l}948 \\
955 \\
\end{array}$ & $\begin{array}{l}1,143 \\
1,150 \\
\end{array}$ & $\begin{array}{l}1,634 \\
1,585 \\
\end{array}$ & $\begin{array}{l}2,554 \\
2,520 \\
\end{array}$ & $\begin{array}{l}3,875 \\
3,978 \\
\end{array}$ & $\begin{array}{l}1,300 \\
1,290 \\
\end{array}$ \\
\hline & Female & $\begin{array}{l}1954-5 \\
1955-6\end{array}$ & $\begin{array}{l}721 \\
674\end{array}$ & $\begin{array}{l}1,046 \\
1,036\end{array}$ & $\begin{array}{l}1,326 \\
1,224\end{array}$ & $\begin{array}{l}1,735 \\
1,588\end{array}$ & $\begin{array}{l}1,780 \\
1,889\end{array}$ & $\begin{array}{l}2,024 \\
1,985\end{array}$ & $\begin{array}{l}2,410 \\
2,417\end{array}$ & $\begin{array}{l}2,892 \\
2,874\end{array}$ & $\begin{array}{l}3,916 \\
3,952 \\
\end{array}$ & - & $\begin{array}{l}1,670 \\
1,640\end{array}$ \\
\hline \multirow{2}{*}{$\begin{array}{l}\text { Spells of Incapacity Com- } \\
\text { mencing in Period, per } \\
100 \text { Persons at Risk .. }\end{array}$} & Male & $\begin{array}{l}1954-5 \\
1955-6\end{array}$ & $\begin{array}{l}34 \\
33 \\
\end{array}$ & $\begin{array}{l}34 \\
35 \\
\end{array}$ & $\begin{array}{l}32 \\
32 \\
\end{array}$ & $\begin{array}{l}32 \\
34 \\
\end{array}$ & $\begin{array}{l}32 \\
33 \\
\end{array}$ & $\begin{array}{l}31 \\
32 \\
\end{array}$ & $\begin{array}{l}33 \\
33\end{array}$ & $\begin{array}{l}37 \\
37\end{array}$ & $\begin{array}{l}41 \\
43\end{array}$ & $\begin{array}{l}43 \\
45 \\
\end{array}$ & $\begin{array}{l}35 \\
35\end{array}$ \\
\hline & Female & $\begin{array}{l}1954-5 \\
1955-6\end{array}$ & $\begin{array}{l}41 \\
40\end{array}$ & $\begin{array}{l}42 \\
42\end{array}$ & $\begin{array}{l}35 \\
35\end{array}$ & $\begin{array}{l}37 \\
36\end{array}$ & $\begin{array}{l}37 \\
39\end{array}$ & $\begin{array}{l}36 \\
37\end{array}$ & $\begin{array}{l}36 \\
37 \\
\end{array}$ & $\begin{array}{l}36 \\
36 \\
\end{array}$ & $\begin{array}{l}34 \\
35 \\
\end{array}$ & - & $\begin{array}{l}38 \\
38\end{array}$ \\
\hline \multirow{2}{*}{$\begin{array}{l}\text { Persons Incapacitated at } \\
\text { Some Time in Period, } \\
\text { per } 100 \text { Persons at Risk }\end{array}$} & Male & $\begin{array}{l}1954-5 \\
1955-6\end{array}$ & $\begin{array}{l}27 \\
26\end{array}$ & $\begin{array}{l}27 \\
27 \\
\end{array}$ & $\begin{array}{l}24 \\
24\end{array}$ & $\begin{array}{l}24 \\
25\end{array}$ & $\begin{array}{l}25 \\
25\end{array}$ & $\begin{array}{l}24 \\
25\end{array}$ & $\begin{array}{l}26 \\
26 \\
\end{array}$ & $\begin{array}{l}30 \\
30\end{array}$ & $\begin{array}{l}36 \\
36\end{array}$ & $\begin{array}{l}41 \\
41\end{array}$ & $\begin{array}{l}28 \\
28 \\
\end{array}$ \\
\hline & Female & $\begin{array}{l}1954-5 \\
1955-6\end{array}$ & $\begin{array}{l}32 \\
30\end{array}$ & $\begin{array}{l}33 \\
32\end{array}$ & $\begin{array}{l}30 \\
28\end{array}$ & $\begin{array}{l}30 \\
29\end{array}$ & $\begin{array}{l}30 \\
33\end{array}$ & $\begin{array}{l}32 \\
31\end{array}$ & $\begin{array}{l}33 \\
34\end{array}$ & $\begin{array}{l}35 \\
34\end{array}$ & $\begin{array}{l}37 \\
37\end{array}$ & - & $\begin{array}{l}32 \\
32\end{array}$ \\
\hline
\end{tabular}

* Including men over age 65 and women over age 60 .

incapacitated in the course of the year was accompanied by a rise in the number of spells commencing in the period as well as in the number of days of incapacity recorded. 
(a) PERSONS INCAPACITATED AT SOME

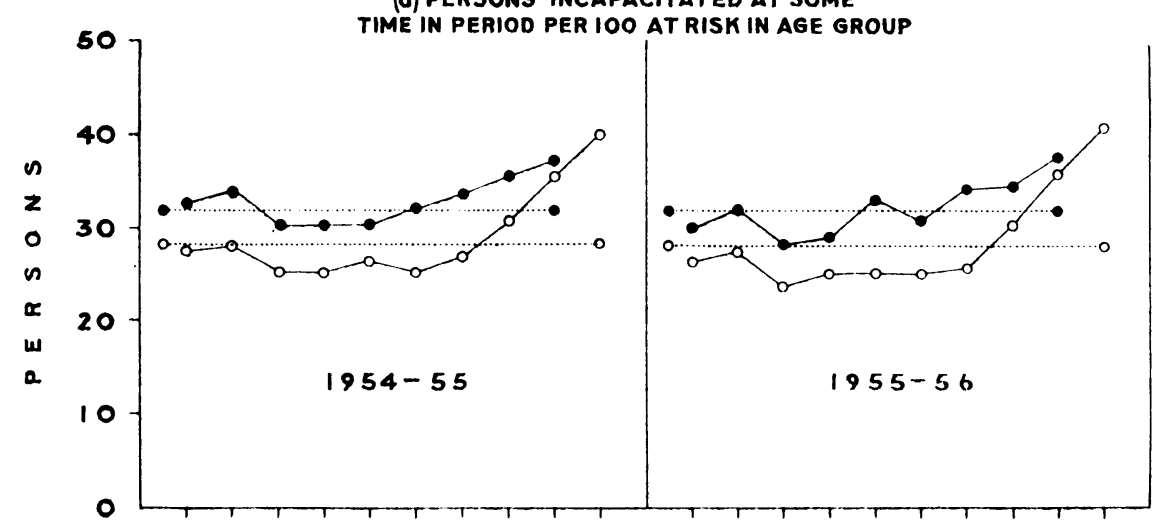

(b) DAYS OF INCAPACITY PER PERSON

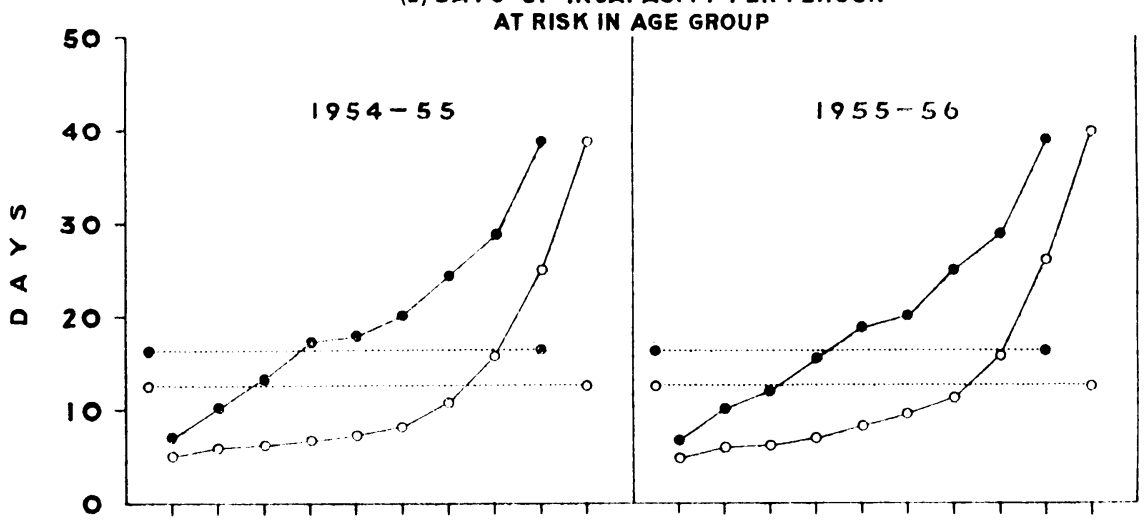

(C) SPELLS OF INCAPACITY COMMENCING

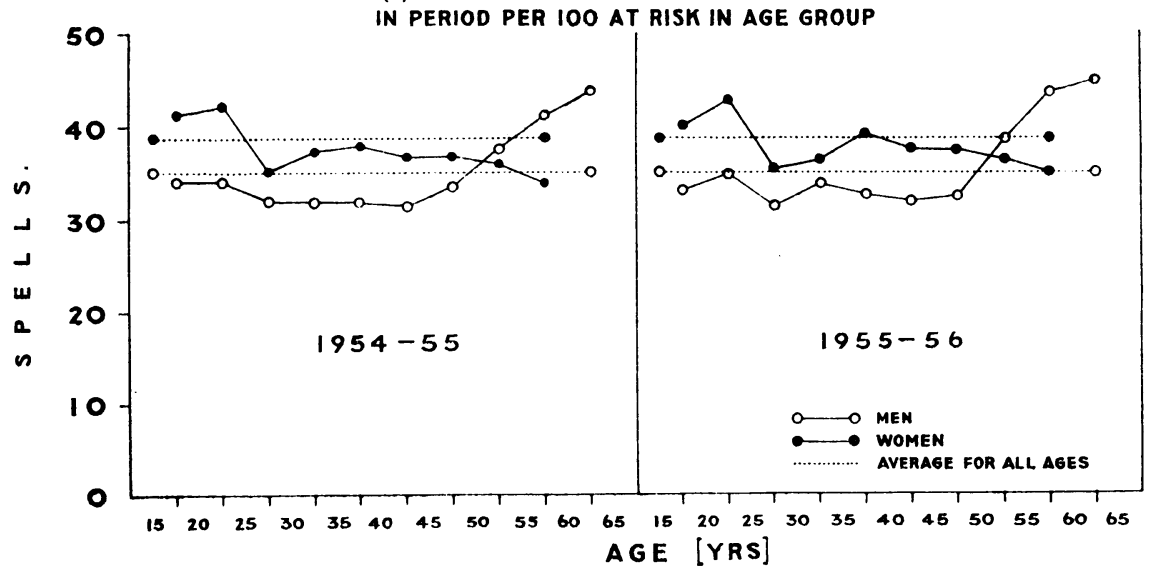

FIG. 2.-Extent of incapacity for work due to sickness in different age gloups. 
Among women the proportion incapacitated was at all points higher than among men. There was the same tendency towards a slightly higher proportion of claimants in the first 10 years of insurance, a not very consistent pattern in the age range $25-39$, and a definite trend upwards from age 40 onwards, the curve rising less steeply than among the men so that the maximum of 37 per hundred at risk in the age range 55-59, which was about the same proportion as was found among men of the same age, was only between a quarter and a third higher than the minimum of 30 (in 1954-55) or 28 (in 1955-56) per hundred at risk in the age range 25-29. However, the number of spells of incapacity per hundred at risk fell gradually from about age $\mathbf{3 5}$ onwards and was actually less than among men after age 50 . The average number of days of incapacity showed the same steep rise as among the men.

The implication that the average duration of incapacity among women over the years followed a different pattern from that of the men, is borne out by Fig. 3 (overleaf) and Table V, which illustrate the proportions of the populations at risk in different age groups which had been incapacitated for one day or more, 6 months or more, and 2 years or more, on June 2, 1956. From age 30 onwards the prevalence of chronic illness was higher among both single and married women than among men aged 50-54; from age 55 the prevalence of chronic illness among men increased steeply but at higher ages the prevalence of illnesses which had lasted at least 6 months among women remained higher than among men 5 years older.

TABLE V

NUMBERS OF MEN, MARRIED WOMEN, AND OTHER WOMEN IN EACH AGE GROUP* INCAPACITATED ON 2nd JUNE 1956, EXPRESSED AS A PERCENTAGE OF THE CORRESPONDING AVERAGE POPULATION AT RISK FOR THE PERIOD 6th JUNE 1955-2nd JUNE 1956 INDICATING DURATION OF INCAPACITY

\begin{tabular}{|c|c|c|c|c|c|c|c|c|c|c|}
\hline \multirow{2}{*}{ Sex } & \multirow{2}{*}{$\cdots$} & \multirow{2}{*}{\multicolumn{3}{|c|}{ Male }} & \multicolumn{6}{|c|}{ Female } \\
\hline & & & & & \multicolumn{3}{|c|}{ Married } & \multicolumn{3}{|c|}{ Other } \\
\hline Duration of Incapacity & . & $\begin{array}{l}1 \text { Day } \\
\text { or More }\end{array}$ & $\begin{array}{l}6 \text { Mnths } \\
\text { or More }\end{array}$ & $\begin{array}{l}2 \text { Yrs } \\
\text { or More }\end{array}$ & $\begin{array}{l}1 \text { Day } \\
\text { or More }\end{array}$ & $\begin{array}{l}6 \text { Mnths } \\
\text { or More }\end{array}$ & $\begin{array}{l}2 \text { Yrs } \\
\text { or More }\end{array}$ & $\begin{array}{l}1 \text { Day } \\
\text { or More }\end{array}$ & $\begin{array}{l}6 \text { Mnths } \\
\text { or More }\end{array}$ & $\begin{array}{l}2 \text { Yrs } \\
\text { or More }\end{array}$ \\
\hline $\begin{array}{l}\text { Number of Persons of } \\
\text { (thousands) }\end{array}$ & $\begin{array}{l}\text { All Ages } \\
\cdots \quad \cdots\end{array}$ & 553 & 234 & 143 & 111 & 52 & 37 & 155 & 75 & 54 \\
\hline $\begin{array}{c}\text { Numbers per Thous- } \\
\text { and Persons at } \\
\text { Risk in Each Age } \\
\text { Group } . .\end{array}$ & $\begin{array}{c}\text { All Ages } \\
15-19 \\
20-24 \\
25-29 \\
30-34 \\
35-39 \\
40-44 \\
45-49 \\
50-54 \\
55-59 \\
60-64\end{array}$ & $\begin{array}{r}3 \cdot 81 \\
1 \cdot 63 \\
1 \cdot 97 \\
1 \cdot 82 \\
2 \cdot 21 \\
2 \cdot 50 \\
2 \cdot 81 \\
3 \cdot 39 \\
4 \cdot 72 \\
7 \cdot 82 \\
11 \cdot 78\end{array}$ & $\begin{array}{l}1 \cdot 61 \\
0 \cdot 16 \\
0 \cdot 39 \\
0 \cdot 43 \\
0 \cdot 61 \\
0 \cdot 74 \\
0 \cdot 94 \\
1 \cdot 29 \\
2 \cdot 06 \\
4 \cdot 12 \\
7 \cdot 38\end{array}$ & $\begin{array}{l}0.99 \\
0.02 \\
0.14 \\
0.21 \\
0.37 \\
0.45 \\
0.60 \\
0.80 \\
1.29 \\
2.64 \\
4.72\end{array}$ & $\begin{array}{r}6 \cdot 43 \\
5 \cdot 80 \\
3 \cdot 87 \\
3 \cdot 97 \\
5 \cdot 12 \\
6 \cdot 79 \\
6 \cdot 83 \\
8 \cdot 07 \\
9 \cdot 30 \\
13 \cdot 04 \\
-\end{array}$ & $\begin{array}{l}3 \cdot 01 \\
0 \cdot 26 \\
0 \cdot 64 \\
1 \cdot 33 \\
2 \cdot 16 \\
3 \cdot 05 \\
3 \cdot 15 \\
4 \cdot 26 \\
5 \cdot 76 \\
8 \cdot 93 \\
-\end{array}$ & $\begin{array}{c}2 \cdot 16 \\
0 \cdot 27 \\
0 \cdot 87 \\
1 \cdot 63 \\
2 \cdot 21 \\
2 \cdot 36 \\
3 \cdot 25 \\
4 \cdot 08 \\
6 \cdot 79 \\
-\end{array}$ & $\begin{array}{r}4 \cdot 27 \\
2 \cdot 14 \\
2 \cdot 41 \\
3 \cdot 19 \\
4 \cdot 23 \\
5 \cdot 24 \\
5 \cdot 73 \\
6 \cdot 97 \\
8 \cdot 90 \\
11 \cdot 10 \\
-\end{array}$ & $\begin{array}{l}2.06 \\
0.26 \\
0.66 \\
1 \cdot 31 \\
2.13 \\
2.75 \\
3.06 \\
4.13 \\
5.66 \\
7.94 \\
-\end{array}$ & $\begin{array}{l}1 \cdot 48 \\
0.06 \\
0.34 \\
0.92 \\
1 \cdot 56 \\
2.05 \\
2.28 \\
3 \cdot 18 \\
4 \cdot 33 \\
6 \cdot 20 \\
-\end{array}$ \\
\hline
\end{tabular}

* Age at December 31, 1955.

TABLE VI

REGIONAL ANALYSIS OF MEN CLAIMING SICKNESS BENEFIT

\begin{tabular}{|c|c|c|c|c|c|c|c|c|c|c|}
\hline \multicolumn{6}{|c|}{ Country and Region } & \multirow{3}{*}{$\begin{array}{c}\begin{array}{c}\text { Estimated } \\
\text { Average } \\
\text { Number } \\
\text { at Risk } \\
\text { (thousands) }\end{array} \\
14,520\end{array}$} & \multicolumn{2}{|c|}{$\begin{array}{l}\text { Incapacitated in the Period } \\
\text { June 6, 1955, to June 2, } 1956\end{array}$} & \multicolumn{2}{|c|}{ Incapacitated on June 2, 1956} \\
\hline & & & & & & & Thousands & Per cent. & Thousands & Per cent. \\
\hline Great Britain & $\cdots$ & . & . & $\cdots$ & .. & & $4074 \cdot 4$ & 28 & $552 \cdot 9$ & $3 \cdot 8$ \\
\hline \multirow[t]{2}{*}{ England } & $\begin{array}{l}\text { Lor } \\
\text { Eas } \\
\text { Sou } \\
\text { Sou } \\
\text { Mic } \\
\text { Nor } \\
\text { Eas } \\
\text { Nor } \\
\text { Nor }\end{array}$ & $\begin{array}{l}\text { n \& } \\
\text { n } \\
\text { ern } \\
\text { Wes } \\
\text { nd } \\
\text { Mid } \\
\text { We } \\
\text { Wes } \\
\text { ern }\end{array}$ & $\begin{array}{l}\text { outh-Ea } \\
\ldots \\
\text { rn } \\
\ddot{\text { ind }} \\
\text { Riding } \\
\text { rn } \\
\ldots\end{array}$ & $\begin{array}{l}\text { ast } \\
\cdots \\
\cdots \\
\cdots \\
\therefore \\
\cdots \\
\cdots\end{array}$ & $\begin{array}{l}\cdots \\
\cdots \\
\cdots \\
\cdots \\
\cdots \\
\cdots\end{array}$ & $\begin{array}{r}3,348 \\
857 \\
726 \\
809 \\
1,432 \\
1,045 \\
1,255 \\
1,928 \\
932\end{array}$ & $\begin{array}{l}768 \cdot 2 \\
221 \cdot 2 \\
177 \cdot 4 \\
220 \cdot 6 \\
362 \cdot 6 \\
293 \cdot 1 \\
395 \cdot 2 \\
572 \cdot 8 \\
329 \cdot 2\end{array}$ & $\begin{array}{l}23 \\
26 \\
24 \\
27 \\
25 \\
28 \\
31 \\
30 \\
35\end{array}$ & $\begin{array}{l}95 \cdot 5 \\
27 \cdot 8 \\
22 \cdot 4 \\
30 \cdot 9 \\
48 \cdot 0 \\
35 \cdot 0 \\
52 \cdot 5 \\
82 \cdot 7 \\
45 \cdot 5\end{array}$ & $\begin{array}{l}2 \cdot 9 \\
3 \cdot 2 \\
3 \cdot 1 \\
3 \cdot 1 \\
3 \cdot 4 \\
3 \cdot 4 \\
4 \cdot 2 \\
4 \cdot 3 \\
4 \cdot 9\end{array}$ \\
\hline & & otal & $\cdots$ & $\cdots$ & $\cdots$ & 12,332 & $3340 \cdot 2$ & 27 & $440 \cdot 2$ & $3 \cdot 6$ \\
\hline Scotland & $\cdots$ & . & $\cdots$ & $\cdots$ & . & 1,455 & $455 \cdot 1$ & 31 & $66 \cdot 9$ & $4 \cdot 6$ \\
\hline Wales $\ldots$ & $\cdots$ & $\cdots$ & $\cdots$ & $\cdots$ & .. & 732 & $276 \cdot 0$ & 38 & $45 \cdot 3$ & $6 \cdot 2$ \\
\hline
\end{tabular}




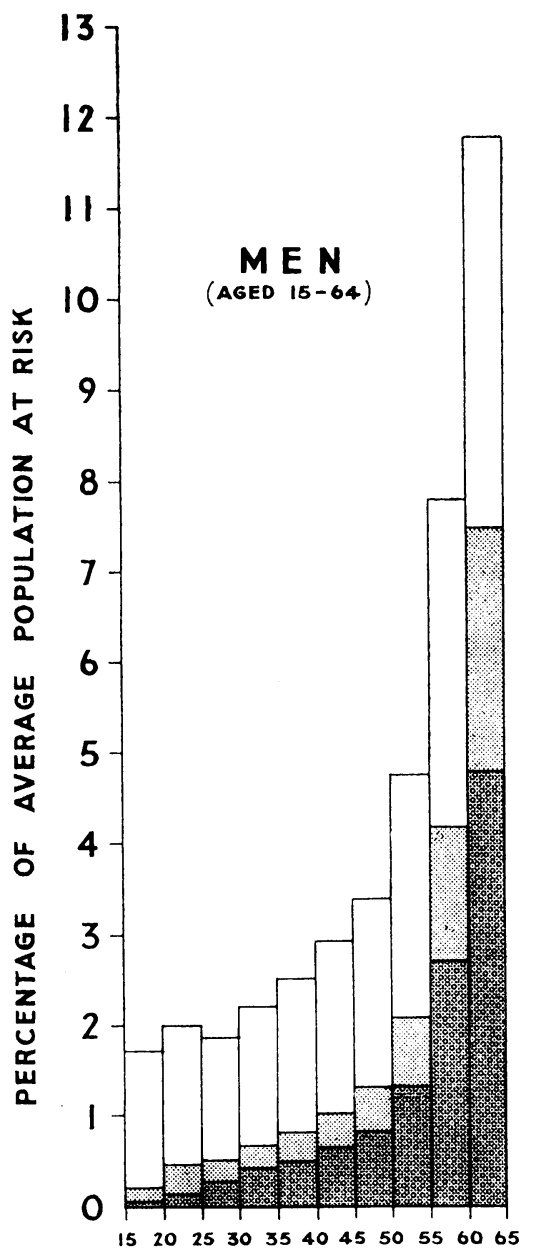

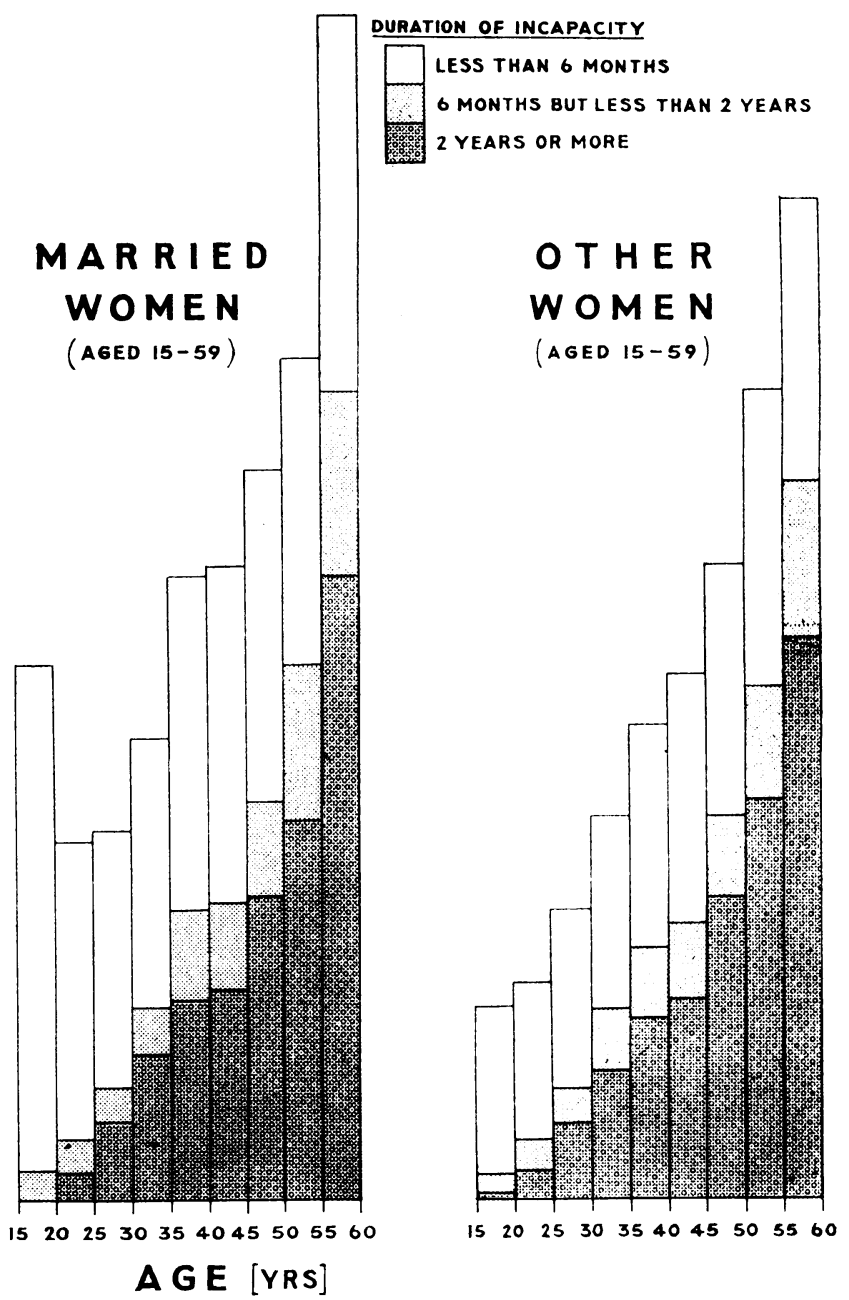

FiG. 3.-Persons incapacitated on June 2, 1956. Numbers of men, married women, and other women expressed as a percentage of the average population at risk in the relevant age group in the year ending on that day. The shading indicates duration of incapacity up to that time

\section{Variations in Different Areas}

The amount of incapacity for work varied in different parts of the country. The distribution of insured women between standard Regions is not known, because the proportion electing not to be insured varies in different areas and this proportion is not measured, but for men the numbers of persons recorded as incapacitated per 100 at risk in each Region has been estimated and is shown separately in Fig. 4 (opposite) and Table VI (p. 79). The causes of differences are probably complex, and the figures are not necessarily a measure of different levels of morbidity.

For instance, when an illness or injury is relatively slight, ability to work may depend on the physical requirements of a man's occupation, and the geographical distribution of occupations with widely different physical requirements may affect rates of incapacity for work in different areas without necessarily meaning that there is more or less "illness"-in the wider sense-in those areas. Similar considerations may influence the length of time needed for recovery from more serious illnesses. 


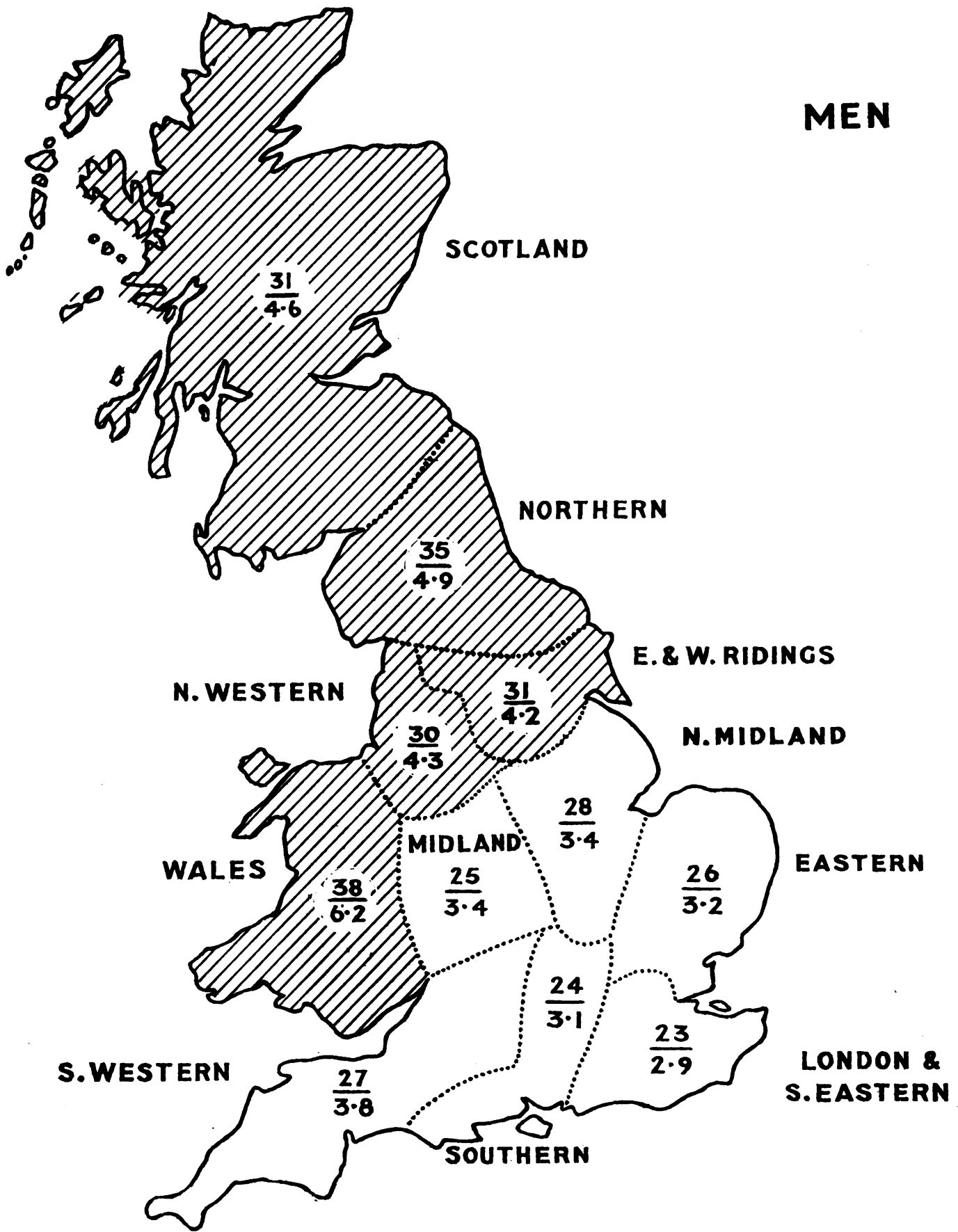

FIG. 4.- Persons incapacitated per 100 at risk in each Standard Region. Above the line, numbers incapacitated at some time in the year; below the line, numbers incapacitated on June 2,1956 . The area above the average is shaded. 
TABLE VII

DAYS OF INCAPACITY FOR WORK* ANALYSED BY MAIN CAUSES

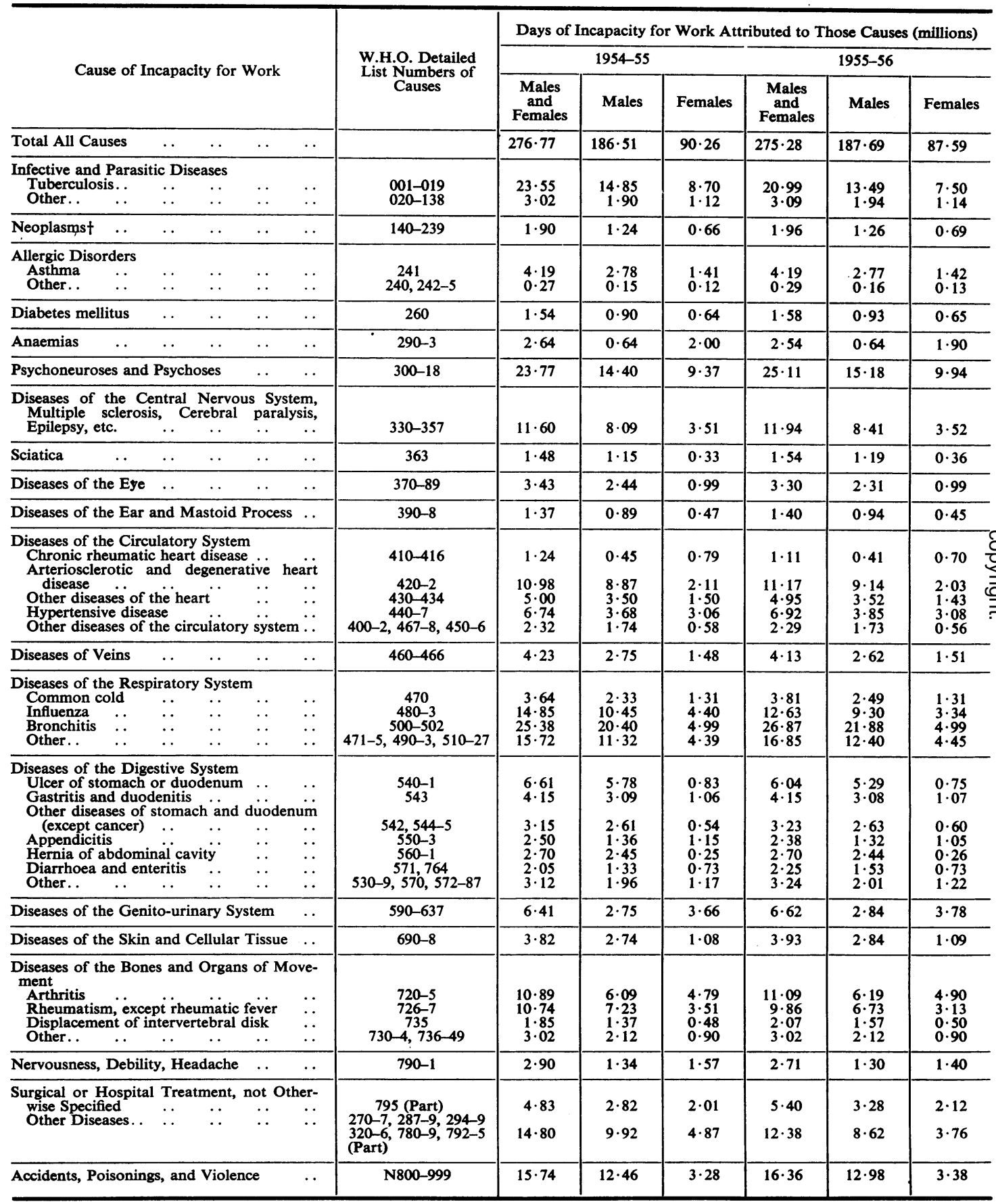

* Monday to Saturday, i.e. six days equals one week; 312 days equal one year. f For obvious reasons, these figures understate the position. 


\section{CAUSES OF INCAPACITY}

The incapacitating causes shown in the medical certificates supporting the claims for sickness benefit are coded according to the World Health Organisation's "International Statistical Classification of Diseases, Injuries, and Causes of Death". Table VII (opposite) shows the main causes of incapacity among the working population. Differences in this Table in the proportionate amount of incapacity due to different groups of causes may indicate real variations be- tween the sexes but do not necessarily do so, because of the widely different age structure in the populations at risk among men and women respectively. The incidence at different ages of certain causes, all responsible for a substantial number of days of incapacity in the course of a year, is therefore shown in Table VIII.

For most of the conditions shown in Table VIII the pattern was, in fact, different for men and for women. For example, in the case of tuberculosis

TABLE VIII

NUMBER OF CLAIMANTS INCAPACITATED AT BEGINNING OF JUNE ANALYSED BY AGE AND SELECTED CAUSES OF INCAPACITY AND EXPRESSED AS A PROPORTION OF THE AVERAGE POPULATION AT RISK IN EACH AGE GROUP

\begin{tabular}{|c|c|c|c|c|c|c|c|c|c|c|c|}
\hline & \multirow{2}{*}{\multicolumn{3}{|c|}{$\cdot$}} & \multirow[b]{2}{*}{ Sex } & \multirow[b]{2}{*}{ Year } & \multicolumn{6}{|c|}{ Age at December $31 *$} \\
\hline & & & & & & $\begin{array}{l}\text { Up to } \\
24\end{array}$ & $25-34$ & $35-44$ & $45-54$ & $55-59$ & $60-64$ \\
\hline & & & & Male & $\begin{array}{l}1954-5 \\
1955-6 \\
\end{array}$ & $\begin{array}{l}2,178 \\
2,194 \\
\end{array}$ & $\begin{array}{l}3,315 \\
3,242 \\
\end{array}$ & $\begin{array}{l}3,142 \\
3,202 \\
\end{array}$ & $\begin{array}{l}3,265 \\
3,323 \\
\end{array}$ & $\begin{array}{l}1,182 \\
1,243\end{array}$ & $\begin{array}{l}977 \\
993\end{array}$ \\
\hline & & & & Female & $\begin{array}{l}1954-5 \\
1955-6\end{array}$ & $\begin{array}{l}2,286 \\
2,289\end{array}$ & $\begin{array}{l}957 \\
938\end{array}$ & $\begin{array}{l}693 \\
673\end{array}$ & $\begin{array}{l}927 \\
907\end{array}$ & $\begin{array}{l}415 \\
416\end{array}$ & - \\
\hline \multirow{16}{*}{$\begin{array}{l}\text { Persons Incapacitated } \\
\text { at End of Statistical } \\
\text { Year (in June) per } \\
10,000 \text { at Risk .. }\end{array}$} & \multirow{2}{*}{ All Causes } & \multirow{2}{*}{$\cdots$} & \multirow{2}{*}{$\cdots$} & Male & $\begin{array}{l}1955 \\
1956\end{array}$ & $\begin{array}{l}181 \\
181 \\
\end{array}$ & $\begin{array}{l}210 \\
202 \\
\end{array}$ & $\begin{array}{l}271 \\
266 \\
\end{array}$ & $\begin{array}{l}423 \\
402 \\
\end{array}$ & $\begin{array}{l}810 \\
782 \\
\end{array}$ & $\begin{array}{l}1,166 \\
1,178 \\
\end{array}$ \\
\hline & & & & Female & $\begin{array}{l}1955 \\
1956\end{array}$ & $\begin{array}{l}249 \\
262\end{array}$ & $\begin{array}{l}419 \\
397\end{array}$ & $\begin{array}{l}575 \\
602\end{array}$ & $\begin{array}{l}835 \\
828\end{array}$ & $\begin{array}{l}1,163 \\
1,186\end{array}$ & - \\
\hline & \multirow{2}{*}{$\begin{array}{c}\text { Tuberculosis of } \\
\text { System }\end{array}$} & \multirow{2}{*}{\multicolumn{2}{|c|}{$\begin{array}{c}\text { Respiratory } \\
\ldots \quad \cdots\end{array}$}} & Male & $\begin{array}{l}1955 \\
1956\end{array}$ & $\begin{array}{l}23 \\
17 \\
\end{array}$ & $\begin{array}{l}28 \\
22\end{array}$ & $\begin{array}{l}29 \\
26\end{array}$ & $\begin{array}{l}30 \\
28\end{array}$ & 38 & 40 \\
\hline & & & & Female & $\begin{array}{l}1955 \\
1956\end{array}$ & $\begin{array}{l}37 \\
29\end{array}$ & $\begin{array}{l}82 \\
66\end{array}$ & $\begin{array}{l}51 \\
52\end{array}$ & $\begin{array}{l}22 \\
22\end{array}$ & $\begin{array}{l}23 \\
21\end{array}$ & - \\
\hline & \multirow{2}{*}{\multicolumn{3}{|c|}{ Psychoneurosis and Psychosis }} & Male & $\begin{array}{l}1955 \\
1956\end{array}$ & $\begin{array}{l}11 \\
12\end{array}$ & $\begin{array}{l}26 \\
27\end{array}$ & $\begin{array}{l}32 \\
34\end{array}$ & $\begin{array}{l}36 \\
38\end{array}$ & & 66 \\
\hline & & & & Female & $\begin{array}{l}1955 \\
1956\end{array}$ & $\begin{array}{l}15 \\
15\end{array}$ & $\begin{array}{l}57 \\
59\end{array}$ & $\begin{array}{r}87 \\
101\end{array}$ & $\begin{array}{l}106 \\
114\end{array}$ & $\begin{array}{l}114 \\
121\end{array}$ & - \\
\hline & \multirow{2}{*}{\multicolumn{3}{|c|}{$\begin{array}{l}\text { Arteriosclerotic and Degener- } \\
\text { ative Heart Disease }\end{array}$}} & Male & $\begin{array}{l}1955 \\
1956 \\
\end{array}$ & 二 & 1 & $\begin{array}{l}4 \\
3 \\
\end{array}$ & $\begin{array}{l}18 \\
18 \\
\end{array}$ & & 119 \\
\hline & & & & Female & $\begin{array}{l}1955 \\
1956\end{array}$ & $\begin{array}{l}1 \\
1\end{array}$ & $\begin{array}{l}4 \\
3 \\
\end{array}$ & $\begin{array}{l}10 \\
13\end{array}$ & $\begin{array}{l}28 \\
27\end{array}$ & $\begin{array}{l}60 \\
65\end{array}$ & 二 \\
\hline & \multirow{2}{*}{\multicolumn{2}{|c|}{ Hypertensive Disease }} & \multirow{2}{*}{$\cdots$} & Male & $\begin{array}{l}1955 \\
1956\end{array}$ & 二 & 二 & $\begin{array}{l}1 \\
1\end{array}$ & $\begin{array}{l}8 \\
7\end{array}$ & \multicolumn{2}{|c|}{28} \\
\hline & & & & Female & $\begin{array}{l}1955 \\
1956\end{array}$ & -1 & $\begin{array}{l}1 \\
2\end{array}$ & $\begin{array}{r}8 \\
10\end{array}$ & $\begin{array}{l}43 \\
43\end{array}$ & $\begin{array}{l}107 \\
119\end{array}$ & - \\
\hline & \multirow{2}{*}{ Bronchitis } & \multirow{2}{*}{$\cdots$} & \multirow{2}{*}{$\cdots$} & Male & $\begin{array}{l}1955 \\
1956\end{array}$ & $\begin{array}{l}6 \\
4 \\
\end{array}$ & $\begin{array}{l}7 \\
7\end{array}$ & $\begin{array}{l}16 \\
14\end{array}$ & $\begin{array}{l}45 \\
39\end{array}$ & \multicolumn{2}{|c|}{$\underbrace{}_{176^{149}}$} \\
\hline & & & & Female & $\begin{array}{l}1955 \\
1956\end{array}$ & $\begin{array}{l}9 \\
8\end{array}$ & $\begin{array}{l}16 \\
13\end{array}$ & $\begin{array}{l}27 \\
32\end{array}$ & $\begin{array}{l}43 \\
49\end{array}$ & $\begin{array}{l}64 \\
70\end{array}$ & - \\
\hline & \multirow{2}{*}{ Arthritis } & \multirow{2}{*}{$\cdots$} & \multirow{2}{*}{$\cdots$} & Male & $\begin{array}{l}1955 \\
1956 \\
\end{array}$ & $\begin{array}{l}1 \\
1 \\
\end{array}$ & $\begin{array}{l}3 \\
2 \\
\end{array}$ & $\begin{array}{l}6 \\
5 \\
\end{array}$ & $\begin{array}{l}16 \\
14 \\
\end{array}$ & \multicolumn{2}{|c|}{$\underbrace{4 \quad 1}_{33 \quad 48}$} \\
\hline & & & & Female & $\begin{array}{l}1955 \\
1956\end{array}$ & $\begin{array}{l}2 \\
1\end{array}$ & $\begin{array}{l}7 \\
6\end{array}$ & $\begin{array}{l}24 \\
25\end{array}$ & $\begin{array}{l}70 \\
73\end{array}$ & $\begin{array}{l}139 \\
143\end{array}$ & - \\
\hline & \multirow{2}{*}{ Rheumation . } & \multirow{2}{*}{$\cdots$} & \multirow{2}{*}{$\cdots$} & Male & $\begin{array}{l}1955 \\
1956\end{array}$ & $\begin{array}{l}4 \\
5\end{array}$ & $\begin{array}{l}7 \\
8\end{array}$ & $\begin{array}{l}13 \\
13 \\
\end{array}$ & $\begin{array}{l}20 \\
16\end{array}$ & \multicolumn{2}{|c|}{$25 \underbrace{31}$} \\
\hline & & & & Female & $\begin{array}{l}1955 \\
1956\end{array}$ & $\begin{array}{l}7 \\
8\end{array}$ & $\begin{array}{l}14 \\
20\end{array}$ & $\begin{array}{l}27 \\
21\end{array}$ & $\begin{array}{l}44 \\
34\end{array}$ & $\begin{array}{l}59 \\
53\end{array}$ & - \\
\hline
\end{tabular}

- e.g. in the case of persons incapacitated on June 4, 1955, age at December 31, 1954. 


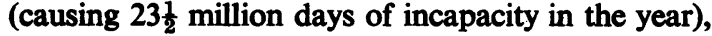
the prevalence rose with age among the men but fell among the women. Another illness attacking young women more than young men but older men more than older women is bronchitis, which was responsible for more incapacity in the year than tuberculosis (over 25 million days). In this instance the disease was more prevalent among women up to about 45 and there was little difference between men and women in the next decade, but though it became increasingly prevalent among older women the prevalence among men aged 55-59 was more than twice as great as that among women of the same age. Over the whole age range up to 60 the prevalence of bronchitis increased between seven and eight times in women and between thirty and forty times in men. On the other hand, psycho-neuroses and psychoses (responsible for nearly 24 million days of incapacity in a year); hypertensive diseases (nearly 7 million), and rheumatism and arthritis (nearly 22 million) increased in prevalence with age more among women than among men.

\section{INDUSTRIAL INJURY BENEFIT}

In the course of the year 1954-55, industrial injury benefit was paid for incapacity covering 18.76 million days, and in 1955-56 the corresponding figure was 19.42 million. The numbers of industrial accidents and the varying incidence of accidents at different ages are indicated in Table IX. The total amount of incapacity for work attracting payment of injury benefit and the incidence of the main external causes in different industries are shown in Table X (overleaf). These Tables do not include certain long-term and some recurrent forms of $\mathscr{D}$ incapacity arising from industrial accidents and prescribed industrial diseases, i.e. where sickness $\frac{3}{8}$ benefit is paid for days of incapacity falling outside ? the injury benefit period (a maximum of 6 months $\vec{F}$ after the date of the accident or development of the disease after which injury benefit is not payable). Nor do they include incapacity caused by pneumoconiosis and byssinosis, diseases which do not

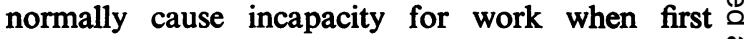
diagnosed, and which do not therefore attract injury is benefit.

\section{Discussion}

From the records of incapacity for work among insured men it is possible to gain an approximate idea of the varying extent of such incapacity among civilian men at different ages between 15-64 other than those who have never been capable of under- $f$ taking any remunerative work; beyond age 65 the 은 picture is blurred by the availability of the retire- ment pension to those whose health prevents or $\frac{7}{2}$ discourages further work.

Among women, however, only about seven in ten $\overrightarrow{0}$ of those in employment and an unknown proportion of the self-employed are insured; the total number represented by analyses of these records amounts to less than one in three of all women of working age, while in some age groups the proportion is very low indeed. The women who are insured are substantially different in their characteristics from those who are not insured, and the sickness records of the two groups are therefore likely to be different, but the extent to which this is true cannot be measured.

TABLE IX

PERSONS EXPERIENCING INDUSTRIAL ACCIDENTS IN GREAT BRITAIN IN THE PERIODS FROM JUNE 7, 1954 TO JUNE 4, 1955, AND FROM JUNE 5, 1955, TO JUNE 2, 1956, ANALYSED BY AGE AND SEX

\begin{tabular}{|c|c|c|c|c|c|c|c|c|c|c|c|c|c|c|}
\hline & \multirow[b]{2}{*}{ Sex } & \multirow[b]{2}{*}{ Year } & \multicolumn{12}{|c|}{ Age at December 31} \\
\hline & & & All ages & $\begin{array}{l}\text { Up } \\
\text { to } \\
19\end{array}$ & $20-24$ & $25-29$ & $30-34$ & $35-39$ & $40-44$ & $45-49$ & $50-54$ & 55-59 & $60-64$ & $\begin{array}{c}65 \\
\text { and } \\
\text { Over }\end{array}$ \\
\hline $\begin{array}{c}\text { Average Population at Risk } \\
\text { (thousands) }\end{array}$ & \multirow{3}{*}{ Male } & $\begin{array}{l}1954-55 \\
1955-56\end{array}$ & $\begin{array}{l}13,341 \\
13,492\end{array}$ & $\begin{array}{r}995 \\
1,015 \\
\end{array}$ & 1,145 & 1,496 & $\begin{array}{l}1,627 \\
1,569\end{array}$ & $\begin{array}{l}1,312 \\
1,392\end{array}$ & $\begin{array}{l}1,504 \\
1,485\end{array}$ & 1,515 & $\begin{array}{l}1,343 \\
1,377\end{array}$ & $\begin{array}{l}1,021 \\
1,079\end{array}$ & $\begin{array}{l}834 \\
854\end{array}$ & $\begin{array}{l}549 \\
556\end{array}$ \\
\hline $\begin{array}{c}\text { Claimants experiencing } \\
\text { Accidents (thousands) }\end{array}$ & & $\begin{array}{l}1954-55 \\
1955-56\end{array}$ & $\begin{array}{l}551 \cdot 7 \\
565 \cdot 44\end{array}$ & \begin{tabular}{|l|}
$52 \cdot 2$ \\
$50 \cdot 84$
\end{tabular} & $\begin{array}{l}52 \cdot 7 \\
54 \cdot 78\end{array}$ & $\begin{array}{l}64 \cdot 6 \\
63 \cdot 66\end{array}$ & $\begin{array}{l}69 \cdot 5 \\
71 \cdot 04\end{array}$ & \begin{tabular}{|l|}
$56 \cdot 3$ \\
$59 \cdot 96$
\end{tabular} & $\begin{array}{l}62 \cdot 3 \\
61 \cdot 36\end{array}$ & $\begin{array}{l}60 \cdot 3 \\
62 \cdot 78\end{array}$ & $\begin{array}{l}54 \cdot 4 \\
56 \cdot 24\end{array}$ & $\begin{array}{l}39 \cdot 1 \\
42 \cdot 36\end{array}$ & $\begin{array}{l}28 \cdot 5 \\
29 \cdot 88\end{array}$ & $\begin{array}{l}11 \cdot 8 \\
12 \cdot 54\end{array}$ \\
\hline 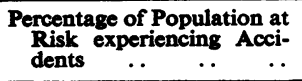 & & $\begin{array}{l}1954-55 \\
1955-56\end{array}$ & $4 \cdot 1$ & $\begin{array}{l}5 \cdot 2 \\
5 \cdot 0\end{array}$ & $\begin{array}{l}4 \cdot 6 \\
4 \cdot 8\end{array}$ & $\begin{array}{l}4 \cdot 3 \\
4 \cdot 3\end{array}$ & $\begin{array}{l}4 \cdot 3 \\
4 \cdot 5\end{array}$ & $\begin{array}{l}4 \cdot 3 \\
4 \cdot 3\end{array}$ & $\begin{array}{l}4 \cdot 1 \\
4 \cdot 1\end{array}$ & $\begin{array}{l}4 \cdot 0 \\
4 \cdot 1\end{array}$ & $\begin{array}{l}4 \cdot 0 \\
4 \cdot 1\end{array}$ & $\begin{array}{r}3 \cdot 8 \\
3 \cdot 9\end{array}$ & $\begin{array}{l}3 \cdot 4 \\
3 \cdot 5\end{array}$ & $\begin{array}{l}2 \cdot 2 \\
2 \cdot 2\end{array}$ \\
\hline $\begin{array}{c}\text { Average Population at Risk } \\
\text { (thousands) }\end{array}$ & \multirow{3}{*}{ Female } & $\begin{array}{l}1954-55 \\
1955-56\end{array}$ & $\begin{array}{l}7,017 \\
7,235\end{array}$ & $\begin{array}{l}1,180 \\
1,182\end{array}$ & $\begin{array}{l}1,026 \\
1,020\end{array}$ & $\begin{array}{l}712 \\
705\end{array}$ & $\begin{array}{l}655 \\
655\end{array}$ & $\begin{array}{l}570 \\
632\end{array}$ & $\begin{array}{l}719 \\
753\end{array}$ & $\begin{array}{l}711 \\
748\end{array}$ & $\begin{array}{l}631 \\
667\end{array}$ & $\begin{array}{l}472 \\
507\end{array}$ & \multicolumn{2}{|c|}{$\begin{array}{c}60 \text { and Over } \\
341 \\
366\end{array}$} \\
\hline $\begin{array}{c}\text { Claimants experiencing } \\
\text { Accidents (thousands) } . .\end{array}$ & & $\begin{array}{l}1954-55 \\
1955-56\end{array}$ & $\begin{array}{l}66 \cdot 0 \\
73 \cdot 16\end{array}$ & $\begin{array}{l}12 \cdot 7 \\
14 \cdot 30\end{array}$ & $\begin{array}{l}7 \cdot 4 \\
7 \cdot 86\end{array}$ & $\begin{array}{l}4 \cdot 5 \\
5 \cdot 32\end{array}$ & $\begin{array}{l}3 \cdot 6 \\
5 \cdot 52\end{array}$ & $\begin{array}{l}6 \cdot 5 \\
6 \cdot 30\end{array}$ & $\begin{array}{l}8 \cdot 4 \\
7 \cdot 76\end{array}$ & $\begin{array}{l}7 \cdot 9 \\
8 \cdot 08\end{array}$ & $\begin{array}{l}7.2 \\
9.04\end{array}$ & $\begin{array}{l}5 \cdot 7 \\
6 \cdot 04\end{array}$ & \multicolumn{2}{|c|}{$\begin{array}{l}2 \cdot 1 \\
2 \cdot 94\end{array}$} \\
\hline $\begin{array}{l}\text { Percentage of Population at } \\
\text { Risk experiencing Acci- } \\
\text { dents }\end{array}$ & & $\begin{array}{l}1054-55 \\
1955-56\end{array}$ & $\begin{array}{l}0.9 \\
1.0\end{array}$ & $\begin{array}{l}1 \cdot 1 \\
1 \cdot 2\end{array}$ & $\begin{array}{l}0 \cdot 7 \\
0 \cdot 8\end{array}$ & $\begin{array}{l}0.6 \\
0.7\end{array}$ & $\begin{array}{l}0.6 \\
0.8\end{array}$ & $\begin{array}{l}1 \cdot 1 \\
1 \cdot 0\end{array}$ & $\begin{array}{l}1 \cdot 2 \\
1.0\end{array}$ & $\begin{array}{l}1-1 \\
1 \cdot 1\end{array}$ & $\begin{array}{l}1 \cdot 1 \\
1 \cdot 4\end{array}$ & $\begin{array}{l}1 \cdot 2 \\
1 \cdot 2\end{array}$ & \multicolumn{2}{|c|}{$\begin{array}{l}0.6 \\
0.8\end{array}$} \\
\hline
\end{tabular}


Women who are not insured include the great majority of housewives with no gainful occupation (a few who were recently employed retain residual rights); those married women in employment who do not consider it worth their while to pay contributions; and widows entitled to widow's benefits of an equivalent amount. Women insured for sickness benefit are for the most part single, including some women widowed in early life and without children; the insured married women are those who for one reason or another have chosen to pay the national insurance contribution. As this covers unemployment, sickness and maternity benefits, and retirement pensions, the reasons for their choice may be complex, and entitlement to sickness benefit may not enter into the question, though a women in poor health may be influenced to insure for that reason. Of those insured, married women in all age groups show a consistent excess of incapacity for work compared with single women. Only some part of the excess among married women would appear to be due to sickness during pregnancy, as only about 5 per cent. of the incapacity for work recorded (for sickness benefit purposes) among all married women (or 9 per cent. among married women aged $15-44)$ is due to conditions directly associated with pregnancy and childbirth.

The analyses for women, then, show only the sickness experienced by the five million women contributing under the national insurance scheme. Conversely, it can perhaps be inferred that any analyses relating to all women in the same age groups would not necessarily be applicable to those women who are insured contributors.

Owing to the fact that many insured persons receiving sickness benefit are no longer on the books of their former employers, the amount of incapacity for work recorded among both men and women is greater than is commonly found among employees, and the figures do not provide a standard against which an employer can measure whether his employees have a good or bad record compared with average absence in industry. The heavy weighting of long-term cases shown in Table III is the cause of the striking difference between the average durations (in the period) of "spells current at some time in the period" (which were as high as 33-34 days for men and 38-39 days among the women) and the median durations of spells ending in the period, which were only 12 and 13 days respectively, in both years.

The trend towards increased incapacity with age was to be expected, but the steepness of the rise in later age groups is striking. Differences between men and women in the pattern of claiming as regards both the numbers of claims at different ages and their duration can be attributed at least in part to the proportionate differences in the causes of their incapacity as shown in Table VIII.

Statistics derived from injury benefit records cover broadly all cases of personal injury caused by accident arising out of and in the course of employment, apart from accidents to non-industrial civil servants and some very minor accidents in other fields of employment. They do not include injuries to the self-employed. Statistics of prescribed industrial diseases have the same coverage. Since the injury benefit period is limited to 6 months, there is not the same piling up of long-term cases that prevents sickness benefit records from indicating the average rate of absence from work due to incapacity among employed persons: injury benefit analyses show the extent of incapacity for work due to industrial injuries or diseases among workers in different industries, and so may provide a measuring rod against which individual enterprises can measure their own standard of absence from these causes among men and women respectively.

\section{SUMMARY}

Some of the statistics included in the Digest of Statistics Analysing Certificates of Incapacity for 1954-55 and 1955-56, circulated by the Ministry of Pensions and National Insurance, are examined to show:

(1) How far incapacity for work among insured persons indicates the extent of such incapacity among men and women in different age groups in Great Britain;

(2) The amount of incapacity recorded for sickness benefit among insured persons in different age groups in each of two years running from the first Monday in June, the extent of recurrent claims, the weight of long-term sickness, and the commoner causes of incapacity among men and women respectively;

(3) Variations in the extent of incapacity for work among insured men in different parts of the country;

(4) The numbers of persons experiencing industrial accidents at different ages, and the numbers of days of incapacity caused by industrial accidents and diseases in different 
INDUSTRIAL ACCIDENTS NDD WORK DAYS* LOST TO INDUSTRY BETWEEN JUNE 6, 1955, AND JUNE 2, 1ळ্ळ6,

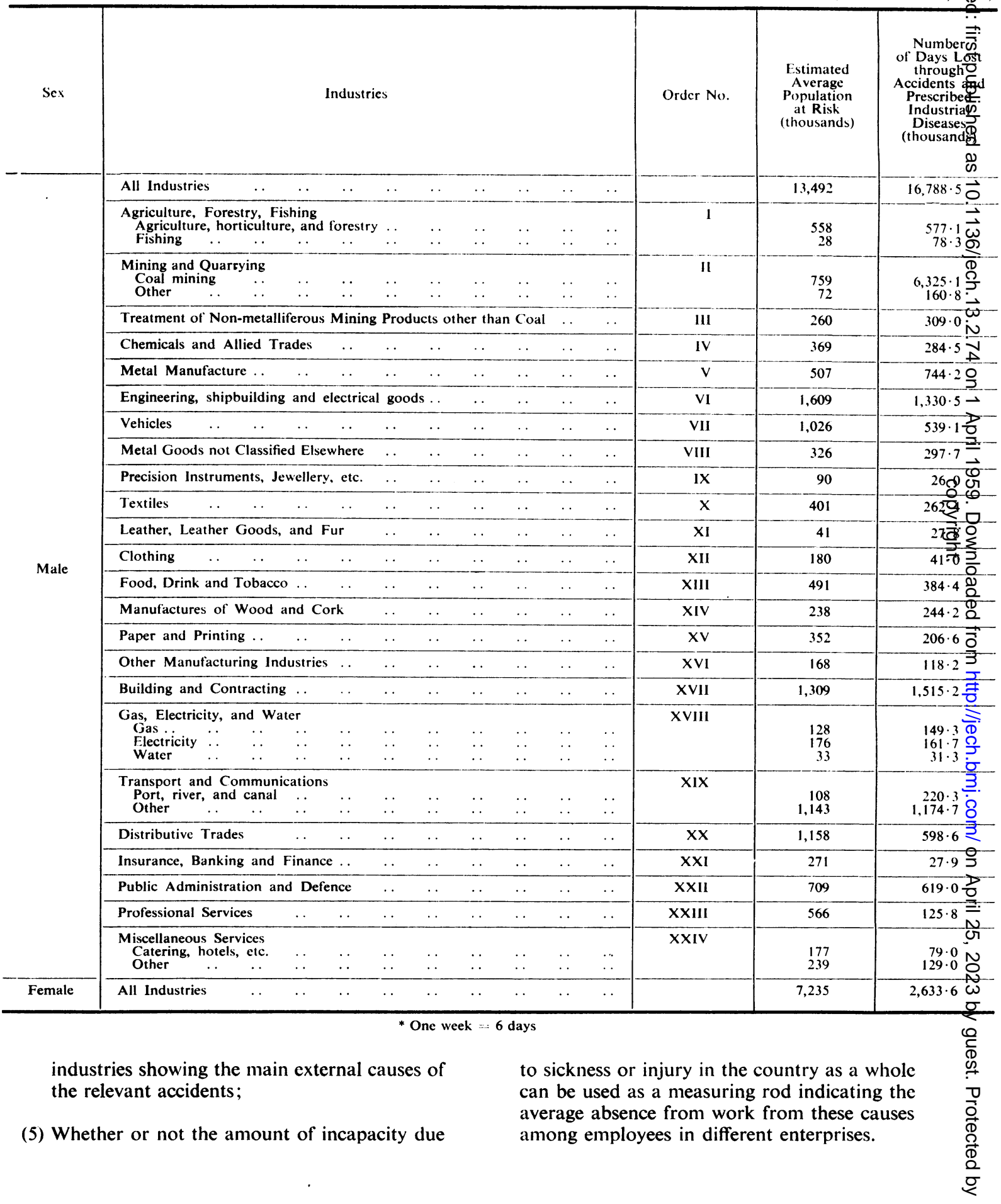


PRESCRIBED INDUSTRIAL DISEASES

INCLUSIVE, SHOWING CAUSES FOR WHICH INJURY BENEFIT WAS PAID

\begin{tabular}{|c|c|c|c|c|c|c|c|c|c|c|c|}
\hline \multicolumn{12}{|c|}{ Days Lost per 100 at Risk } \\
\hline \multirow[b]{2}{*}{ All } & \multicolumn{10}{|c|}{ Loss Caused by Accidents due to: } & \multirow[b]{2}{*}{$\begin{array}{l}\text { Loss } \\
\text { Caused by } \\
\text { Prescribed } \\
\text { Industrial } \\
\text { Diseases }\end{array}$} \\
\hline & $\begin{array}{c}\text { Motor } \\
\text { Vehicles }\end{array}$ & $\begin{array}{c}\text { Other } \\
\text { Transport }\end{array}$ & $\begin{array}{c}\text { Other } \\
\text { Vehicles } \\
\text { (e.g. } \\
\text { conveyor } \\
\text { tubs and } \\
\text { baggage } \\
\text { cars) }\end{array}$ & Falls & Machinery & $\begin{array}{c}\text { Fire, } \\
\text { Explosion, } \\
\text { Hot or } \\
\text { Corrosive } \\
\text { Substance, } \\
\text { or } \\
\text { Radiation } \\
\end{array}$ & $\begin{array}{c}\text { Blow from } \\
\text { Falling } \\
\text { Object }\end{array}$ & $\begin{array}{c}\text { Cutting or } \\
\text { Piercing } \\
\text { Instru- } \\
\text { ments }\end{array}$ & $\begin{array}{c}\text { Foreign } \\
\text { Body } \\
\text { entering } \\
\text { Eye or } \\
\text { Adnexa }\end{array}$ & Other & \\
\hline 124 & 4 & 3 & 6 & 28 & 11 & 3 & 26 & 6 & 2 & 29 & 7 \\
\hline $\begin{array}{l}103 \\
280\end{array}$ & $\begin{array}{l}3 \\
1\end{array}$ & $\begin{array}{r}1 \\
176\end{array}$ & 4 & $\begin{array}{l}31 \\
26\end{array}$ & $\begin{array}{l}13 \\
14 \\
\end{array}$ & $\begin{array}{l}1 \\
1\end{array}$ & $\begin{array}{l}8 \\
9\end{array}$ & $\begin{array}{l}11 \\
25\end{array}$ & $\underline{2}$ & $\begin{array}{l}28 \\
18\end{array}$ & $\begin{array}{r}1 \\
10\end{array}$ \\
\hline $\begin{array}{l}833 \\
223\end{array}$ & 1 & 1 & $\begin{array}{l}72 \\
14 \\
\end{array}$ & $\begin{array}{r}141 \\
53 \\
\end{array}$ & $\begin{array}{l}55 \\
17 \\
\end{array}$ & $\begin{array}{l}4 \\
3 \\
\end{array}$ & $\begin{array}{r}269 \\
60 \\
\end{array}$ & $\begin{array}{r}18 \\
7 \\
\end{array}$ & $\begin{array}{r}13 \\
4 \\
\end{array}$ & $\begin{array}{r}198 \\
53 \\
\end{array}$ & $\begin{array}{r}61 \\
3 \\
\end{array}$ \\
\hline 119 & 3 & 一 & 6 & 25 & 13 & 4 & 21 & 7 & 1 & 31 & 7 \\
\hline 77 & 3 & 1 & 1 & 19 & 7 & 7 & 10 & 2 & 1 & 18 & 9 \\
\hline 147 & 2 & - & 5 & 23 & 16 & 16 & 29 & 8 & 3 & 38 & 7 \\
\hline 83 & 1 & 3 & 2 & 18 & 12 & 2 & 15 & 4 & 2 & 19 & 5 \\
\hline 53 & 2 & - & 2 & 10 & 6 & 1 & 8 & 4 & 2 & 13 & 5 \\
\hline 91 & - & - & 4 & 11 & 14 & 6 & 17 & 9 & 4 & 21 & 5 \\
\hline 29 & - & - & - & 6 & 3 & 1 & 2 & 2 & 2 & 8 & 4 \\
\hline 65 & 1 & - & 1 & 14 & 19 & 4 & 6 & 3 & - & 11 & 6 \\
\hline 68 & - & 1 & 1 & 9 & 15 & 2 & 3 & 11 & - & 14 & 11 \\
\hline 23 & - & - & - & 4 & 5 & - & 2 & 4 & - & 5 & 2 \\
\hline 78 & 5 & - & 2 & 21 & 7 & 4 & 9 & 6 & - & 19 & 5 \\
\hline 103 & 6 & - & 1 & 17 & 29 & - & 13 & 12 & 1 & 19 & 5 \\
\hline 59 & 3 & - & 1 & 14 & 13 & 1 & 9 & 3 & - & 9 & 3 \\
\hline 70 & - & - & 3 & 9 & 14 & 2 & 9 & 5 & - & 18 & 10 \\
\hline 116 & 3 & 1 & 2 & 45 & 7 & 3 & 17 & 7 & 2 & 23 & 5 \\
\hline $\begin{array}{r}117 \\
92 \\
95 \\
\end{array}$ & $\begin{array}{l}2 \\
5 \\
1 \\
\end{array}$ & $\frac{1}{2}$ & $\begin{array}{r}5 \\
1 \\
- \\
\end{array}$ & $\begin{array}{l}36 \\
26 \\
27 \\
\end{array}$ & $\begin{array}{r}7 \\
4 \\
14 \\
\end{array}$ & $\begin{array}{l}5 \\
5 \\
2 \\
\end{array}$ & $\begin{array}{l}12 \\
11 \\
13 \\
\end{array}$ & $\begin{array}{l}4 \\
5 \\
8 \\
\end{array}$ & $\begin{array}{r}\overline{2} \\
2\end{array}$ & $\begin{array}{l}39 \\
29 \\
27 \\
\end{array}$ & $\begin{array}{l}5 \\
4 \\
1 \\
\end{array}$ \\
\hline $\begin{array}{l}204 \\
103\end{array}$ & $\begin{array}{r}4 \\
12\end{array}$ & $\begin{array}{l}49 \\
20\end{array}$ & $\begin{array}{l}7 \\
3\end{array}$ & $\begin{array}{l}30 \\
25\end{array}$ & $\begin{array}{r}15 \\
3\end{array}$ & $\overline{1}$ & $\begin{array}{l}50 \\
11\end{array}$ & $\begin{array}{l}8 \\
3 \\
\end{array}$ & $\overline{1}$ & $\begin{array}{l}36 \\
22 \\
\end{array}$ & $\begin{array}{l}4 \\
3 \\
\end{array}$ \\
\hline 52 & 5 & 1 & 2 & 15 & 3 & 1 & 6 & 5 & - & 13 & 1 \\
\hline 10 & 2 & - & - & 3 & - & - & - & - & - & 3 & 1 \\
\hline 87 & 10 & 2 & 2 & 28 & 3 & 2 & 8 & 5 & 1 & 21 & 4 \\
\hline 22 & 1 & - & 1 & 8 & 1 & - & 2 & 1 & - & 6 & 3 \\
\hline $\begin{array}{l}45 \\
54\end{array}$ & $\overline{2}$ & 1 & $\overline{1}$ & $\begin{array}{l}18 \\
23\end{array}$ & 1 & $\begin{array}{l}2 \\
4\end{array}$ & $\begin{array}{l}5 \\
2\end{array}$ & $\begin{array}{l}3 \\
3\end{array}$ & $=$ & $\begin{array}{l}11 \\
15\end{array}$ & $\begin{array}{l}3 \\
3\end{array}$ \\
\hline 36 & 1 & - & - & 12 & 5 & 1 & 3 & 4 & - & 6 & 4 \\
\hline
\end{tabular}

t $A$ few unpaid waiting days are included.

I am most grateful to Mr. D. Newman of the Ministry of Pensions and National Insurance, Newcastle, for much helpful advice, to Mr. R. Woods and Miss D. M. Heal of the Statistics Division, London, for preparing the
Tables, to Sir Arthur Massey, Chief Medical Officer, and Dr. W. D. T. Brunyate of the Medical Department, for their interest, and to the Secretary of the Ministry for permission to publish this article. 